\title{
Biotin studies in pigs
}

\section{Biotin availability in feedstuffs for pigs and chickens}

\author{
BY J. S. KOPINKSI, JANE LEIBHOLZ* AND W. L. BRYDEN \\ Department of Animal Husbandry, University of Sydney, Camden, \\ New South Wales 2570, Australia
}

(Received 22 September 1988-Accepted 14 June 1989)

\begin{abstract}
Six pigs (initial weight $30 \mathrm{~kg}$ ) were fitted with T-shaped cannulas in the ileum, $0-3 \mathrm{~m}$ from the ileocaecal junction. Each pig was given each of seven diets for a $10 \mathrm{~d}$ period. The diets contained wheat (var. Banks and Egret), barley, sorghum, meat meai, soya-bean meal or casein as test feedstuffs. The apparent digestibilities of biotin to the ileum of the pigs were $0.06,-0.03,-1.23,0.18,0.82,0.12$ and 0.95 for the diets containing wheat (var. Banks), wheat (var. Egret), sorghum, barley, meat meal, soya-bean meal and casein respectively. The same diets were given to 168 chickens. Digesta were collected from the terminal ileum after $7 \mathrm{~d}$. The apparent digestibilities of biotin to the ileum of the chickens were $0 \cdot 11$, $-0.10,-0.73,0.05,0.69,0.28$ and 0.75 for the diets containing wheat (var. Banks), wheat (var. Egret), sorghum, barley, meat meal, soya-bean meal and casein respectively.
\end{abstract}

\section{Biotin availability: Ileal digestibility : Chicken: Pig}

The response of pigs to dietary supplementation with biotin has been variable (Kornegay 1986), and one of the factors likely to contribute to the variation is the availability of biotin in feedstuffs. Although there are only two recent studies on the availability of biotin to the pig (Misir \& Blair, 1988; Sauer et al. 1988), there are numerous reports on the availability of biotin to the chick. Growth assays have been used most frequently (Wagstaff et al. 1961; Frigg, 1976, 1984; Anderson et al. 1978) in the evaluation of the availability of biotin in feeds for chickens. The activity of pyruvate carboxylase (EC 6.4.1.1) in blood (Whitehead et al. 1982) and liver (Anderson et al. 1978), and the biotin content of egg-yolk (Buenrostro \& Kratzer, 1984) and of plasma (Buenrostro \& Kratzer, 1984; Frigg, 1984) have also been used for this purpose. The use of the availability values produced by these methods in chickens in the formulation of pig diets is questionable, however, in view of marked differences in the processes of digestion in the two species. Tagwerker (1978), quoting the unpublished results of L. Volker and co-workers, suggested that biotin from wheat was of low availability for the pig as had been found for the chicken (Frigg, 1976). Misir \& Blair (1988), using the concentration of biotin in the plasma, also found a good correlation for the availability of biotin for the pig and the turkey poult, but Sauer et al. (1988) found large differences in the availability of biotin in feedstuffs for poultry and in the digestibility of biotin in pigs determined at the end of the small intestine.

The present experiments were designed to estimate the availability of biotin in feed ingredients routinely used in Australian pig diets by measuring biotin digestibility at the ileum of the pig. The diets were also given to chickens to determine ileal digestibility and so allow a comparison of the availability of biotin between chickens and pigs. 


\section{MATERIALS AND METHODS}

\section{Pigs}

Six Landrace-Large White entire male pigs, of initial live weight approximately $30 \mathrm{~kg}$, were fitted with single T-shaped cannulas in the ileum. The cannula was located approximately $0.3 \mathrm{~m}$ from the ileocaecal junction. The pigs were housed in metabolism cages. Water was provided ad lib. from nipple drinkers.

The feeding of the pelleted, experimental diets (Table 1) commenced $14 \mathrm{~d}$ after surgery. Diets 1-6 (Table 1) were given for $10 \mathrm{~d}$ each in a Latin square design while diet 7 , the maize flour-casein diet, was given for $10 \mathrm{~d}$ in the final collection period 7 to all six pigs as a control. Feed intake was restricted to $1.5 \mathrm{~kg} / \mathrm{d}$ for collection periods $1-3$ and $2.0 \mathrm{~kg} / \mathrm{d}$ for collection periods 47 . The daily intake was delivered at four hourly intervals by an automatic belt feeder. From day 3 to day 7 of each collection period, the diets were sprayed with indigestible markers CrEDTA ( $280 \mathrm{mg}$ chromium $/ \mathrm{kg}$ diet) and ytterbium nitrate (160 $\mathrm{mg}$ ytterbium/kg diet).

Ileal digesta were collected for $3 \mathrm{~d}$ from day 4 to day 7 of each collection period. Digesta were collected over an $8 \mathrm{~h}$ period each day at about $1.5 \mathrm{~h}$ intervals. A total of about 200 $\mathrm{ml}$ digesta was collected from each pig during each collection period. Each interval's sample portion was bulked and frozen immediately at $-20^{\circ}$ as the day progressed. Faeces were collected twice daily for $3 \mathrm{~d}$, from day 9 of each period until the beginning of day 1 of the next period, and were frozen immediately at $-20^{\circ}$. Urine was collected into I M-sulphuric acid for $2 \mathrm{~d}$. The urine was bulked, subsampled and stored at $-20^{\circ}$.

\section{Chickens}

Male broiler chickens $(168 ; 35 \mathrm{~d}$ of age) were allocated by restricted randomization on initial weight to twenty-eight groups. Each group was housed in a cage that was situated in an air-conditioned $\left(24^{\circ}\right)$ and continuously illuminated room. The experimental diets (Table 1), sprayed with the indigestible markers CrEDTA and $\mathrm{Yb}$, were each given to four groups of chickens for $7 \mathrm{~d}$. During the experiment food and water were provided ad lib.

Total excreta were collected on day 6 , at four-hourly intervals for $12 \mathrm{~h}$ and dried immediately at $95^{\circ}$ in a fan-forced oven. The following day each bird was given a lethal dose of sodium pentobarbitone by intracardiac injection. The terminal ileum, determined as the distal half of the small intestine between the vitelline diverticulum and the ileocaecal junction, was removed and the contents were gently expelled with $2 \mathrm{ml}$ water into a chilled container. The ileal contents of the six birds in each group were bulked and stored at $-20^{\circ}$.

\section{Analytical methods}

Dry matter (DM) was determined for feed, faeces and digesta samples in a forced-air oven at $95^{\circ}$ for $24 \mathrm{~h}$. Total nitrogen was analysed by a Kjeldahl method (Kjel Foss, Foss Electric, Denmark). Contents of $\mathrm{Cr}$ and $\mathrm{Yb}$ were analysed using $\mathrm{DM}$ samples digested in perchloric-nitric acids $(1 ; 3, \mathrm{v} / \mathrm{v})$, and measured using an atomic absorption spectrophotometer (Varian, Los Altos, California). Biotin was analysed using dry samples hydrolysed in $1 \mathrm{M}-\mathrm{H}_{2} \mathrm{SO}_{4}$ by the procedure of Hood (1977). The biotin in feed was also measured microbiologically (Lactobacillus plantarum) by Hoffman-La Roche, Basle, Switzerland. Urine samples were filtered, neutralized with $\mathrm{NaOH}$, then concentrated 20 fold by drying overnight at $95^{\circ}$ before biotin estimation by the method of Hood (1977).

The flow of digesta was calculated from the mean concentration of indigestible markers.

\section{Statistical analysis}

All pig observations were subjected to a Latin Square statistical analysis; chicken observations were subjected to one-way analysis of variance (Steel \& Torrie, 1980). 
Table 1. Composition of diets

\begin{tabular}{|c|c|c|c|c|c|c|c|}
\hline \multirow{2}{*}{$\begin{array}{l}\text { Variable ingredients } \\
\qquad(\mathrm{g} / \mathrm{kg})\end{array}$} & \multicolumn{7}{|c|}{ Diets } \\
\hline & BWC & EWC & $\mathrm{SC}$ & $\mathrm{BC}$ & $\mathrm{CMM}$ & CSBM & $\mathrm{CC}$ \\
\hline Maize flour & $9 \cdot 3$ & $7 \cdot 8$ & 0.7 & $5 \cdot 2$ & 676 & $600 \cdot 7$ & $705 \cdot 3$ \\
\hline Casein & $35 \cdot 3$ & $88 \cdot 7$ & $70 \cdot 7$ & $65 \cdot 0$ & - & - & 1910 \\
\hline Wheat (var. Banks) & $927 \cdot 7$ & - & - & - & 一 & - & - \\
\hline Wheat (var. Egret) & - & $874 \cdot 3$ & - & - & - & 一 & - \\
\hline Sorghum & - & $\ldots$ & $896 \cdot 3$ & - & - & - & - \\
\hline Barley & -- & - & $\ldots$ & $902 \cdot 0$ & 一 & - & - \\
\hline Meat meal & - & - & - & - & $316 \cdot 8$ & - & - \\
\hline Soya-bean meal & - & - & - & - & - & 3500 & - \\
\hline Dicalcium phosphate & 13.8 & $17 \cdot 7$ & $18 \cdot 9$ & $15 \cdot 1$ & $一$ & $20 \cdot 1$ & $27 \cdot 0$ \\
\hline Limestone & 80 & $6 \cdot 2$ & $6 \cdot 1$ & $7 \cdot 4$ & - & $3 \cdot 6$ & 3.0 \\
\hline Potassium chloride & - & - & - & - & - & - & $4 \cdot 4$ \\
\hline Sodium chloride & $2 \cdot 6$ & $2 \cdot 6$ & $2 \cdot 6$ & $2 \cdot 6$ & $2 \cdot 6$ & $2 \cdot 6$ & $2 \cdot 1$ \\
\hline Magnesium sulphate & - & - & $\ldots$ & - & - & - & $4 \cdot 0$ \\
\hline Maize oil & - & - & - & - & - & $20 \cdot 0$ & $20 \cdot 0$ \\
\hline Calcium stearate & -- & - & - & - & - & - & $20 \cdot 0$ \\
\hline Methionine & - & - & $2 \cdot 0$ & - & $2 \cdot 0$ & $0 \cdot 3$ & - \\
\hline Lysine & 0.6 & - & - & - & - & $一$ & - \\
\hline Solkafloc & - & - & - & - & $20 \cdot 0$ & - & $20 \cdot 0$ \\
\hline Vitamin and mineral premix* & $4 \cdot 0$ & $4 \cdot 0$ & 40 & $4 \cdot 0$ & $4 \cdot 0$ & $4 \cdot 0$ & $4 \cdot 0$ \\
\hline \multicolumn{8}{|l|}{ Biotin contents $(\mu \mathrm{g} / \mathrm{kg})$} \\
\hline Microbiological assay & 109 & 89 & 294 & 129 & 30 & 78 & 25 \\
\hline Isotope-dilution assay & 91 & 79 & 226 & 120 & 32 & 82 & 32 \\
\hline
\end{tabular}

* Supplying (mg/kg diet): 1.5 retinol, 0.025 cholecalciferol, $20 \alpha$-tocopherol, 2 menadione, $26 \mu \mathrm{g}$ cyanocobalamin, 1.5 thiamin, 4 ribolavin, 26 niacin, 16 pantothenic acid, 2 pyridoxine, 1000 choline, 1 folic acid, 100 iron, 10 copper, 40 manganese, 70 zinc, $0 \cdot 1$ iodine, $0 \cdot 1$ selenium. Other additives $(\mathrm{mg} / \mathrm{kg}): 50$ ethoxyquin.

\section{RESULTS}

Radioisotope and microbiological analyses were used to assess the biotin content of the diets and the two methods gave similar results (Table 1). The highest biotin content was measured in the sorghum (SC) diet; the level in this diet was two to three times that detected in all other diets assayed. The diets containing wheat (BWC and EWC), barley (BC) and soya-bean meal (CSBM) had similar biotin contents, and the lowest biotin contents were found in the meat meal (CMM) and casein (CC) diets (Table 1).

Flow of DM (Table 2) from the ileum in pigs indicated a digestion of about $70 \%$ for all diets examined except diet $\mathrm{CC}$ where the digestibility was $83 \%$. Between the ileum and the faeces the flow of DM decreased to $8 \cdot 6,8.7$ and $7.3 \%$ of the original intake in diets $\mathrm{BWC}$, EWC and SC respectively. In diets BC and CMM the decreases in DM flow were to 16 and $14 \%$ of the original intakes respectively.

Nitrogen flow values in Table 2 indicated that all diets except CMM and CC provided a similar apparent digestion of $\mathrm{N}$ (about $83 \%$ ) to the ileum. The $\mathrm{N}$ digestion of diet $\mathrm{CMM}$ was lower. Diet $\mathrm{CC}$ had a higher apparent digestion of $\mathrm{N}$ to the ileum. The apparent digestion of $\mathrm{N}$ over the whole tract was similar for all diets, with diet CMM having a slightly lower apparent $\mathrm{N}$ digestion over the whole tract and diet $\mathrm{CC}$ a higher apparent $\mathrm{N}$ digestion.

The mean retention of $\mathrm{N}$ over all the collection periods and diets was about $21 \mathrm{~g}$. The $N$ retention for diet CMM was significantly less than that of the other six diets.

The flow of biotin to the ileum was variable between diets, with diets BWC, EWC, BC and CSBM having ileal biotin flows close to biotin intakes. Diet CMM had a significantly 
Table 2. The flow of dry matter, nitrogen and biotin from the ileum of pigs given diets based on wheat, var. Banks $(B W C)$ and var. Egret (EWC), sorghum (SC), barley (BC), soya-bean meal (CSBM), meat meal (CMM) or casein $(C C)^{*}$

(Mean values for six pigs)

\begin{tabular}{|c|c|c|c|c|c|c|c|c|}
\hline Diet... & BWC & EWC & $\mathrm{SC}$ & $\mathrm{BC}$ & CMM & CSBM & SEM & $\mathrm{CC}$ \\
\hline \multicolumn{9}{|l|}{ Dry matter $(g / d)$} \\
\hline Intake & 1574 & 1574 & 1572 & 1570 & 1570 & 1575 & - & 1806 \\
\hline Ileal flow & 430 & 438 & 470 & 579 & 388 & 468 & 15.7 & 303 \\
\hline Faeces & 136 & 137 & 115 & 253 & 216 & 80 & $13 \cdot I$ & 88 \\
\hline \multicolumn{9}{|l|}{$N(g / d)$} \\
\hline Intake & $46 \cdot 0$ & $48 \cdot 0$ & $47 \cdot 3$ & $47 \cdot 1$ & $45 \cdot 2$ & $47 \cdot 9$ & - & $56 \cdot 2$ \\
\hline Ileal flow & $7 \cdot 45$ & 7.35 & $12 \cdot 13$ & $10 \cdot 48$ & 18.55 & $13 \cdot 79$ & 0.686 & $8 \cdot 5$ \\
\hline Faeces & 3.33 & $2 \cdot 85$ & 4.53 & $4 \cdot 90$ & $8 \cdot 18$ & $3 \cdot 52$ & 0.410 & $2 \cdot 28$ \\
\hline Retention & $21 \cdot 5$ & $24 \cdot 3$ & $24 \cdot 2$ & $21 \cdot 1$ & $14 \cdot 3$ & $27 \cdot 3$ & 0.75 & $19 \cdot 7$ \\
\hline \multicolumn{9}{|l|}{ Biotin $(\mu \mathrm{g} / \mathrm{d})$} \\
\hline Intake & 144 & 125 & 355 & 188 & 50 & 130 & $7 \cdot 07$ & 22 \\
\hline Ileal flow & 136 & 129 & 791 & 154 & 9 & 115 & $25 \cdot 1$ & 1 \\
\hline Faeces & 266 & 253 & 389 & 358 & 128 & 218 & $28 \cdot 5$ & 97 \\
\hline Urine & 52 & 37 & 34 & 72 & 81 & 75 & $7 \cdot 7$ & $25 t$ \\
\hline Balance & -174 & -165 & -68 & -242 & -159 & -163 & $21 \cdot 2$ & -100 \\
\hline $\begin{array}{l}\text { Apparent ileal } \\
\text { digestibility of } \\
\text { biotin }\end{array}$ & 0.06 & -0.03 & $-1 \cdot 23$ & 0.18 & 0.82 & $0 \cdot 12$ & 0.14 & 0.95 \\
\hline
\end{tabular}

* For details, see Table 1 and p. 774 .

$\uparrow$ Values from four pigs.

lower flow of biotin to the ileum compared with the intake ( $18 \%$ of intake). For diet SC the flow of biotin to the ileum was $222 \%$ of the intake.

The biotin excretion in the faeces of all pigs was significantly greater than the biotin intake for all the diets given.

The excretion of biotin as a percentage of intake in the urine of pigs given the various diets was 162 for diet CMM but only 10-38 for the other diets.

As the excretion of biotin in faeces was greater than biotin intake, the biotin balance was negative for all diets, ranging from $-68 \mu \mathrm{g} / \mathrm{d}$ in diet SC to $-242 \mu \mathrm{d}$ for the diet $\mathrm{BC}$. Using apparent digestion of biotin to the ileum as an indicator of its availability, the availabilities of biotin for the diets BWC, EWC, SC, BC, CMM, CSBM and CC were calculated as 6, - 3, $-123,18,82,12$ and $95 \%$ respectively.

The DM flow (Table 3) to the lleum in chickens was similar for the diets EWC, SC and $\mathrm{BC}$ at about $36 \%$ of intake. For diets CMM and CSBM the values were marginally lower at $27 \%$ of intake, while for diet CC the flow was significantly lower at $15 \%$ of intake. Diet BWC gave a significantly higher flow of DM from the ileum (69\% of intake). The faecal excretion of DM for diet BWC was also significantly higher at $52 \%$ of intake, with diets EWC, SC, BC and CSBM having a faecal DM flow of approximately $29 \%$ of intake. Diet $\mathrm{CC}$ had a significantly lower faecal excretion of DM than the other diets; however, the faecal DM flow was higher than that observed in the ileum. As in the pig, the flow of biotin from the ileum of chickens (Table 3) was similar to intake for diets BWC, EWC, BC, CMM and CSBM. Diet SC again gave a flow of biotin from the ileum greater than the intake, but not to the same extent as was observed in the pig.

For diets BWC, EWC and BC, the excretion of biotin was less than the biotin intake, whereas for diets SC, CMM, CSBM and CC the excretion of biotin was greater than the 
Table 3. The flow of dry matter $(D M)$ and biotin from the ileum in chickens given diets based on wheat, var. Banks $(B W C)$ and var. Egret $(E W C)$, sorghum $(S C)$, barley $(B C)$, soya-bean meal (CSBM), meat meal (CMM) or casein $(C C)^{*}$

(Mean values for four groups of six chickens)

\begin{tabular}{|c|c|c|c|c|c|c|c|c|}
\hline Diet ... & BWC & EWC & $\mathrm{SC}$ & $\mathrm{BC}$ & CMM & CSBM & $\mathrm{CC}$ & SEM \\
\hline \multicolumn{9}{|c|}{ DM (as proportion of intake) } \\
\hline Intake & 1.000 & 1.000 & 1.000 & 1.000 & 1.000 & 1.000 & 1.000 & - \\
\hline Ileal flow & 0.690 & $0 \cdot 361$ & 0.338 & 0.411 & 0.258 & 0.276 & 0.143 & 0.0267 \\
\hline Excreta & 0.518 & 0.312 & 0.288 & 0.347 & 0.215 & 0.268 & 0.184 & 0.0249 \\
\hline \multicolumn{9}{|c|}{ Biotin ( $\mu \mathrm{g} / \mathrm{kg} \mathrm{DM}$ intake) } \\
\hline Intake & 91 & 79 & 226 & 120 & 32 & 82 & 12 & - \\
\hline Ileal flow & 81 & 87 & 391 & 114 & 10 & 59 & 3 & 11.5 \\
\hline Excreta & 68 & 70 & 422 & 114 & 40 & 96 & 50 & $9 \cdot 3$ \\
\hline $\begin{array}{l}\text { Apparent ileal } \\
\text { digestibility of } \\
\text { biotin }\end{array}$ & 0.11 & $-0 \cdot 10$ & -0.73 & 0.05 & 0.69 & 0.28 & 0.75 & 0.071 \\
\hline
\end{tabular}

* For details, see Table 1.

biotin intake. Thus the biotin balance was positive for diets BWC, EWC and BC at 23, 9 and $6 \mu \mathrm{g} / \mathrm{d}$ respectively and negative for diets SC, CMM, CSBM and CC at $-196,-8$, -14 and $-38 \mu \mathrm{g} / \mathrm{d}$ respectively.

Using the apparent ileal digestibility as an indicator of availability, the availabilities of biotin for chickens in diets BWC, EWC, SC, BC, CMM, CSBM and CC were calculated as $11,-10,-73,5,69,28$ and $75 \%$ respectively.

\section{DISCUSSION}

As stressed earlier, indices used to estimate the availability of biotin in poultry feed ingredients have included growth, pyruvate carboxylase activity in the liver and plasma, and biotin levels in plasma and egg-yolk. Unfortunately, few of the techniques used to study biotin availability in the chicken can be used in the pig. The activity of pyruvate carboxylase in the blood of pigs (Whitehead et al. 1980) is too low for the enzyme to be a sensitive indicator of biotin status and previous studies (Kopinski et al. 1989a) indicated that growth responses cannot be utilized. The concentration of biotin in plasma is a poor guide to biotin status unless large numbers of animals are used for each diet, as there is a large variation between animals. Misir \& Blair (1988) found a correlation $\left(r^{2}\right)$ of 0.7 between the biotin intake and its concentration in the plasma. Measurement of apparent digestibility at the ileum is currently used for amino acid availability studies (Low, 1982; Sauer \& Ozimek, 1986) and the technique has been applied to the availability of biotin in feedstuffs for chickens (Bryden, 1982) and pigs (Sauer et al. 1988).

The measurements of the flow of DM and $\mathbf{N}$ from the ileum in pigs indicated that these were extensively digested before the terminal ileum. The flow of biotin at the ileum for the various diets indicated that the digestion and absorption, and hence the availability of biotin, were not related to the digestion of DM or $\mathrm{N}$. Three possible reasons for this poor digestion of biotin are as follows. First, the biotin is complexed to some dietary ingredient which is not hydrolysed before reaching the terminal ileum. (Sauer et al. (1988) found that the absorption of free biotin at the ileum was almost complete.) Second, the biotin has been hydrolysed at the terminal ileum but has passed the site of a carrier-mediated absorption 
site. A third possibility is that the biotin from the feedstuff has been absorbed and the biotin detected in the ileum is derived from microbiological synthesis of biotin in the small intestine or backflow of microbial biotin from the caecum and large intestine.

The apparent digestibilities of biotin at the ileum in pigs and chickens were similar. For diets BWC, EWC, SC, BC, CMM, CSBM and CC the values were 6, - 3, - 123, 18, 82, 12 and $95 \%$ respectively. In the chicken, the corresponding values for the same diets were $11,-10,-73,5,69,28$ and $75 \%$. Diets CC and CMM were of low biotin content but of high biotin digestibility and hence a small variation in the estimation of the flow of biotin to the ileum would have resulted in a large variation in the estimate of availability. The high digestibility of biotin in casein and meat meal is not unexpected as casein is highly digestible and the processing of meat meal employs conditions known to liberate biotin and this would lead to a higher available biotin content. On the other hand, the removal of excess fat and water during the rendering process could cause the loss of free biotin from the final meat meal product (Wilder, 1973).

The reasons for the negative digestibility of biotin from diets SC and EWC are not known. The small negative value for diet EWC may be within experimental error but the magnitude of the value for the sorghum diet for both chickens and pigs suggests that some components of sorghum are having an influence on biotin digestibility. The mechanism is not apparent from this study but it could involve formation of unabsorbable biotin complexes, enhancement of microbial biotin synthesis or stimulation of the retrograde flow of digesta from the hind-gut to the ileum. Tannins in sorghum, for example, reduce the digestibility of amino acids by binding to proteins and forming complexes that are resistant to proteolytic enzymes or by binding directly to enzymes (Cousins et al. 1981). Further studies are required to determine the reason for the high ileal flow of biotin in pigs and chickens given sorghum diets.

Antibiotics should be incorporated into diets as a means of suppressing microbial activity or gnotobiotic animals used in subsequent investigations.

The digestibility of biotin determined in the present experiments, either with the chicken or the pig, indicated that commonly used Australian feedstuffs are generally poor sources of available biotin. In general, biotin availability from cereal grains is lower than from protein feedstuffs for both pigs and poultry. However, there is much variation in the reported values. These differences could result from the techniques used or arise from differences in geographical location, agronomic practices or processing conditions. These factors all influence biotin content (Payne, 1977; Tagwerker, 1978; Klaui, 1979) and presumably also its availability from feedstuffs. Other factors including level of dietary inclusion (Steiff et al. 1986), interaction with other dietary ingredients (Misir \& Blair, 1988) and the activity of the gut microflora have all been shown to influence biotin availability.

In conjunction with measurement of ileal digestibility of biotin we measured excretion of biotin in urine and faeces. The faecal excretion of biotin observed in the pigs is independent of their dietary biotin intake. However, the variable excretion of biotin in faeces from pigs given different diets suggests that the level of biotin excreted is dependent on dietary composition. Examination of the organic matter digestion post-ileally and the faecal flow of biotin suggest a relationship which is modulated by another variable. This variable is probably the carbohydrate substrate that is available for the microflora of the hind-gut.

The urinary excretion of biotin may be a suitable criterion for measurement of biotin availability as it relates to biotin absorbed from the gut. Urinary excretion of biotin in biotin-deficient pigs of similar weight was about $35 \mu \mathrm{g} / \mathrm{d}$ (Kopinski et al. 1989 b). If it is assumed that this biotin is excreted irrespective of biotin intake, then the availability of biotin expressed as a percentage of intake corrected for this endogenous loss can be calculated, and then diets BWC, EWC, SC, BC, CMM and CSBM have biotin availabilities 
of $12,2,-1,20,92$ and $30 \%$ respectively. It is noteworthy that Gardner et al. $(1945,1946)$ found a good correlation between intake and urinary excretion of biotin in normal human volunteers. Urinary biotin excretion remained at approximately the same level throughout a period of $50 \mathrm{~d}$ starvation in man (Swendseid et al. 1965), and this is further support for correcting urinary biotin excretion with values determined in depleted animals because of the slow turnover of the protein-bound biotin pool (Wolf et al. 1985) for endogenous loss. Moreover, as the excretion rate of free biotin is rapid, even in depleted animals (Lee et al. 1973) and birds (Frigg, 1978), this would indicate that the amount of biotin that can be deposited in the tissue-bound biotin pool is limited. However, as with ileal digestibility, any contribution or absorption of microbiologically synthesized biotin would limit the application of these techniques.

In conclusion, more studies need to be conducted to determine the biotin availability of feedstuffs for pigs and the validity of extrapolating values determined with chickens to pigs. From the results of this study it would seem that urinary excretion of biotin should be further evaluated as a possible measure of biotin availability in the pig.

This study was made possible by the support of the Australian Pig Council. The authors wish to thank Mrs R. Smith, Mr J. McClure and Mrs J. Gill for technical assistance.

\section{REFERENCES}

Anderson, P. A., Baker, D. H. \& Mistry, S. P. (1978). Bioassay determination of the biotin content of corn, barley, sorghum and wheat. Journal of Animal Science 47, 654-659.

Bryden, W. L. (1982). Nutritional and hormonal aspects of biotin metabolism in the fowl. PhD Thesis, University of Sydney.

Buenrostro, J. L. \& Kratzer, F. H. (1984). Use of plasma and egg yolk biotin of White Leghorn hens to assess biotin availability from feedstuffs. Poultry Science 63, 1563-1570.

Cousins, B. W., Tanksley, T. D. Jr, Knabe, D. A. \& Zebrowska, T. (1981). Nutrient digestibility and performance of pigs fed sorghums varying in tannin concentration. Journal of Animal Science 53, 1524-1537.

Frigg, M. (1976). Bio-availability of biotin in cereals. Poultry Science 55, 2310-2318.

Frigg, M. (1978). Uptake and excretion of $\left[{ }^{3} \mathrm{H}\right]$ biotin in chicks. Proceedings of the World Poultry Congress, Rio de Janeiro, Brazil, pp. 32-39.

Frigg, M. (1984). Available biotin content of various feed ingredients. Poultry Science 63, 750-753.

Gardner, J., Neal, A. L., Peterson, W. H. \& Parsons, H. T. (1945). Human biotin metabolism on various levels of biotin intake. Archives of Biochemistry 8, 339-348.

Gardner, J., Parsons, H. T. \& Peterson, W. H. (1946). Human utilization of biotin from various diets. American Journal of Medical Science 211, 198-204.

Hood, R. L. (1977). Use of linear regression analysis in the isotope dilution assay of biotin. Analytical Biochemistry 79, 635-638.

Klaui, H. (1979). Inactivation of vitamins. Proceedings of the Nutrition Society 38, 135-141.

Kopinski, J. S. \& Leibholz, J. (1989). Biotin studies in pigs. 2. The biotin requirement of the growing pig. British Journal of Nutrition 62, 761-766.

Kopinski, J. S., Leibholz, J., Bryden, W. L. \& Fogarty, A. C. (1989a). Biotin studies in pigs. 1. Biotin deficiency in the young pig. British Journal of Nutrition 62, 751-759.

Kopinski, J. S., Leibholz, J. \& Love, R. J. (1989b). Biotin studies in pigs. 5. The post-ileal absorption of biotin. British Journal of Nutrition 62, 781-789.

Kornegay, E. T. (1986). Biotin in swine production: a review. Livestock Production Science 14, 65-89.

Lee, H. M., Wright, L. D. \& McCormick, D. B. (1973). Metabolism in the rat, of biotin injected intra-peritoneally as the avidin-biotin complex. Proceedings of the Society of Experimental Biology and Medicine 142, 439-442.

Low, A. G. (1982). Digestibility and availability of amino acids from feedstuffs for pigs: a review. Livestock Production Science 9, 511-520.

Misir, R. \& Blair, R. (1984). Bioavailable biotin from cereal grains for broiler chicks as affected by added dietary fibre. Poultry Science 63, Suppl. 1, 152.

Misir, R. \& Blair, R. (1988). Biotin availability from protein supplements and cereal grains for weanling pigs. Canadian Journal of Animal Science 68, 523-532.

Payne, C. G. (1977). Nutritional syndromes in poultry in relation to wheat-based diets. In Nutrition and the Climatic Environment, pp. 155-174 [W. Haresign, H. Swan and D. Lewis, editors]. London: Butterworths.

Sauer, W. C., Mosenthin, R. \& Ozimek, L. (1988). The digestibility of biotin in protein supplements and cereal grains for growing pigs. Journal of Animal Science 66, 2583-2589. 
Sauer, W. C. \& Ozimek, L. (1986). Digestibility of amino acids in swine: results and their practical applications: a review. Livestock Production Science 15, 367-388.

Steel, R. G. D. \& Torrie, J. H. (1980). Principles and Procedures of Statistics, 2nd ed. New York: McGraw Hill. Steiff, K., Volker, L. \& Frigg, M. (1986). Availability of biotin from feed ingredients to growing pigs. Proceedings of the Sixth International Conference of Production Diseases in Farm Animals, Belfast, UK, pp. 112-115.

Swendseid, M. E., Schick, G., Vineyard, E. \& Drenick, E. J. (1965). Vitamin excretion studies in starving obese subjects: some possible interpretations for vitamin nutriture. American Journal of Clinical Nutrition 17, $272-276$

Tagwerker, F. J. (1978). Roche Information Service Bulletin no. 1675. Basle: Roche Products Ltd.

Wagstaff, R. K., Dobson, D. C. \& Anderson, J. O. (1961). Available biotin content of barley. Poultry Science 40 , 503-509.

Whitehead, C. C., Armstrong, J. A. \& Waddington, D. (1982). The determination of the availability to chicks of biotin in feed ingredients by a bioassay based on the response of blood pyruvate carboxylase $(E C$ 6.4.1.1) activity. British Journal of Nutrition 48, 81-88.

Whitehead, C. C., Bannister, D. W. \& D'Mello, J. P. F. (1980). Blood pyruvate carboxylase activity as a criteria of biotin status in young pigs. Research in Veterinary Science 29, 126-128.

Wilder, O. H. M. (1973). Effect of processing a meat meal and other meat products. In Proceedings of Symposium, Gainesville, Florida, 1972, pp. 282-285. Washington DC: National Academy of Sciences.

Wolf, B., Grier, R. E., Secor McVoy, J. R. \& Heard, G. S. (1985). Biotinidase deficiency: a noval vitamin recycling defect. Journal of Inherited Metabolic Disorders 8, 53-58. 